\title{
Leukocyte Telomere Length in Alzheimer's Disease Patients with a Different Rate of Progression
}

\author{
Enzo Tedone $^{\mathrm{a}}$, Beatrice Arosio ${ }^{\mathrm{a}, \mathrm{b}, *}$, Federico Colombo $^{\mathrm{c}}$, Evelyn Ferri ${ }^{\mathrm{a}}$, Delphine Asselineau ${ }^{\mathrm{d}, \mathrm{e}, \mathrm{f}}$, \\ Francois Piette $^{\mathrm{g}}$, Cristina Gussago ${ }^{\mathrm{a}}$, Joel Belmin ${ }^{\mathrm{g}}$, Sylvie Pariel ${ }^{\mathrm{g}}$, Khadija Benlhassan ${ }^{\mathrm{d}}$, \\ Martina Casati ${ }^{\mathrm{a}}$, Anne Bornand ${ }^{\mathrm{g}}$, Paolo Dionigi Rossi ${ }^{\mathrm{b}}$, Paolo Mazzola ${ }^{\mathrm{h}}$, Giorgio Annoni ${ }^{\mathrm{h}}$, \\ Mohamed Doulazmi ${ }^{\mathrm{e}, \mathrm{f}, \mathrm{g}}$, Jean Mariani ${ }^{\mathrm{e}, \mathrm{f}, \mathrm{g}}$, Laura Porretti ${ }^{\mathrm{c}}$, Dorothy H. Bray ${ }^{\mathrm{d}}$ and Daniela Mari ${ }^{\mathrm{a}, \mathrm{b}}$ \\ ${ }^{\mathrm{a}}$ Geriatric Unit, Department of Medical Sciences and Community Health, University of Milan, Milan, Italy \\ ${ }^{\mathrm{b}}$ Geriatric Unit, Fondazione IRCCS Ca' Granda, Ospedale Maggiore Policlinico, Milan, Italy \\ ${ }^{\mathrm{c}}$ Flow Cytometry Service, Fondazione IRCCS Ca' Granda, Ospedale Maggiore Policlinico, Milan, Italy \\ d ImmunoClin Ltd, London, UK \\ ${ }^{\mathrm{e}}$ UPMC University Paris 06, UMR 8526 Biological Adaptation and Ageing (B2A) Team Brain Development, Repair \\ and Aging (BDRA), Paris, France \\ ${ }^{\mathrm{f}}$ CNRS, UMR 8526 Biological Adaptation and Ageing (B2A) Team Brain Development, Repair and Aging (BDRA), \\ Paris, France \\ ${ }^{\mathrm{g}}$ AP-HP, DHU FAST GH Pitie-Salpêtrière-Charles Foix, Paris, France. \\ ${ }^{\mathrm{h}}$ Geriatric Clinic, Department of Health Science, Milan Center for Neuroscience, University Study of Milano- \\ Bicocca, Milan, Italy
}

Handling Associate Editor: Daniela Galimberti

Accepted 18 March 2015

\begin{abstract}
.
Background: Age and short leukocyte telomeres have been associated with a higher risk of Alzheimer's disease (AD). Inflammation is involved in AD and it is suggested that anti-inflammatory interleukin-10 (IL-10) may partly antagonize these processes.

Objective: The aim is to correlate telomere length (TL) in peripheral blood mononuclear cells (PBMC) from patients with $\mathrm{AD}$ to disease progression rate. Moreover, we evaluated whether TL was associated with IL-10 production by unstimulated or amyloid- $\beta(\mathrm{A} \beta)$-stimulated PBMC.

Methods: We enrolled 31 late-onset AD and 20 age-matched healthy elderly (HE). After a two-year follow-up period, patients were retrospectively evaluated as slow-progressing (ADS) (Mini Mental State Examination (MMSE) decline over the two years of follow-up $\leq 3$ points) or fast progressing $\mathrm{AD}$ (ADF) (MMSE decline $\geq 5$ points). TL was measured by flow cytometry and in vitro IL-10 production by enzyme-linked immunosorbent assay.

Results: TL (mean \pm SD) for HE, ADS, and ADF was $2.3 \pm 0.1,2.0 \pm 0.1$, and $2.5 \pm 0.1 \mathrm{~Kb}$, respectively. ADS showed a shorter TL compared to HE $(p=0.034)$ and to ADF $(p=0.005)$. MMSE decline correlated with TL in AD $\left(\mathrm{R}^{2}=0.284 ; p=0.008\right)$. We found a significant difference in IL-10 production between unstimulated and A $\beta$-stimulated PBMC from ADS (40.7 \pm 13.7
\end{abstract}

\footnotetext{
*Correspondence to: Beatrice Arosio, PhD, Geriatric Unit, Department of Medical Sciences and Community Health, University
}

of Milan, Via Pace 9, 20122 Milan, Italy. Tel.: +39 02 55035405; Fax: +3902 50320735; E-mail: beatrice.arosio@unimi.it. 
versus $59.0 \pm 27.0 ; p=0.004)$ but not from $\operatorname{ADF}(39.7 \pm 14.4$ versus $42.2 \pm 22.4)$. HE showed a trend toward significance $(47.1 \pm 25.4$ versus $55.3 \pm 27.9 ; p=0.10)$.

Conclusion: PBMC from ADF may be characterized by an impaired response induced by $\mathrm{A} \beta$ and by a reduced proliferative response responsible for the longer telomeres. TL might be a contributing factor in predicting the rate of AD progression.

Keywords: Alzheimer's disease, disease progression, interleukin-10, peripheral blood mononuclear cells, telomere

\section{INTRODUCTION}

Alzheimer's disease (AD) is the major cause of dementia in the elderly. It is commonly accepted that $\mathrm{AD}$ pathology starts years to decades before the onset of cognitive symptoms [1]. This fact explains why symptomatic AD consistently represents an advanced stage of AD pathology [2].

Amyloid plaques and neurofibrillary tangles are the pathological hallmarks of AD. However considering $\mathrm{AD}$ as a single, well-defined entity has become an obstacle to lucid analysis of the problem of dementia in old age. Whereas in early-onset patients, AD might be best described as a purely degenerative disease with an important role for amyloid- $\beta(A \beta)$ in the pathogenesis; in late-onset patients, the probability of finding other abnormalities is increased [3-7]. To date, $90 \%$ of all patients with $\mathrm{AD}$ in the population are older than 75 years, and $75 \%$ of patients are over 80 years of age [8]. This data suggest that aging and pathophysiological changes it induces may be joint causes of AD onset and progression in older patients.

Telomeres are specialized sequences consisting of highly conserved TTAGGG repeats [9-11] that cap the ends of linear chromosomal DNA, protecting the genome from damage and preserving chromosome stability [10, 12-14]. However, because of their end positions, telomeres are not fully duplicated during DNA replication and thus become shorter with each cell division [15-17]. This process limits the replicative lifespan of many different cells that, eventually, enter a senescent status or trigger apoptosis [18-23]. Telomere length (TL) reflects not only cellular turnover but also the exposure to oxidative and inflammatory damage [24-29] and, accordingly, may be a marker of both biological age and mortality risk [27, 30-32] that predicts incidence of age-related diseases [33-37]. To date, investigations on blood cells have been inconsistent in relationship between TL and AD [38-47]. In particular, several studies reported that TL is associated with cognitive decline in elders [48-51] and is shorter in patients with AD [38-44], but other studies showed TL is not associated with either levels of cognitive performance or age-related cognitive change [52, 53] and cannot be used in elderly as marker to diagnose the early phase of cognitive impairment (mild cognitive impairment), to distinguish between demented and non-demented patients and/or the type of dementia [45-47].

A growing body of literature shows that inflammation is involved in the neurodegeneration process [54-58] and can furthermore accelerate telomere shortening [26-29], which, in turn, may be linked with the pathogenesis of AD [38-44, 59-61]. Interestingly, it is suggested that anti-inflammatory cytokines, like interleukin-10 (IL-10), may partly antagonize these processes [62, 63]. In particular, IL-10 has been suggested to play an important role in neuronal homeostasis and may also be able to inhibit $\mathrm{A} \beta$ - or lipopolysaccharide (LPS)-induced generation of proinflammatory cytokines [64].

To investigate the contribution of telomere shortening to the onset and progression rate of $\mathrm{AD}$, we measured TL in peripheral blood mononuclear cells (PBMC) from late-onset patients with $\mathrm{AD}$ and agematched controls, and we correlated it with disease progression rate. We also assessed whether TL was associated with IL-10 production by resting and $A \beta-$ or LPS-stimulated PBMC. Here we report that TL is directly associated with the rate of cognitive decline during the follow-up period and may thus be considered as a predictive marker of $\mathrm{AD}$ progression rate. In addition, an impaired response to $A \beta$ stimulus may contribute to cause a faster $\mathrm{AD}$ progression.

\section{MATERIALS AND METHODS}

\section{Participants and setting}

A total of 51 individuals were enrolled in the study: 20 healthy elderly (HE) (mean age $79.1 \pm 8.4$ years old) and 31 patients with $\mathrm{AD}$ (mean age 80.6 \pm 5.1 years old). Subjects diagnosed with AD fulfilled the criteria of dementia and the criteria of AD defined by NINCDS-ADRDA [65]. All individuals were Caucasians living in Milan or Paris and belonged to larger populations of outpatients.

The criteria for the diagnosis of normal cognition were: 1) no active neurological or psychiatric disorder; 2) no ongoing medical problems or related treatments 
interfering with cognitive function; 3) a normal neurological exam; 4) no psychoactive medications, and 5) the ability to live and function independently in the community.

Individuals affected by cancer, cardiovascular diseases, autoimmune disorders, inflammatory diseases, and active neurological or psychiatric disorders were excluded from the study. We also excluded subjects who exhibited signs of inflammation (as stated by hemogram and C-reactive protein level) at the time of blood draw.

All participants and their relatives gave informed consent and the study protocol was approved by the respective ethics committees.

At baseline, physical, neurological, and neuropsychological examinations were performed for all patients with AD together with clinical history, computed tomography or magnetic resonance imaging scan, and cognitive testing using Mini-Mental State Examination (MMSE). Laboratory analyses included apolipoprotein E (ApoE) genotype assessment and biochemical tests.

After a two-year period of follow-up, patients with $\mathrm{AD}$ were retrospectively evaluated and $\mathrm{AD}$ progression rate was calculated by using deltaMMSE score (MMSE score at recruitment - MMSE score after the two-year period of follow-up). Subsequently, patients were divided into slow (ADS) and fast (ADF) decliners according to their rate of decline, that is lower or higher than the median rate of decline in the total population during the two-year period of follow-up (3.5 points) [66]. As the size of our study groups is quite small, we employed more stringent classification criteria and we defined patients showing a deltaMMSE $\leq 3$ points and no appearance of new cognitive disorders and/or physical deterioration as ADS and patients showing a deltaMMSE $\geq 5$ points and appearance of new cognitive disorders as ADF. Noteworthy, all diagnoses of slow or fast progressing $\mathrm{AD}$ were confirmed by clinicians.

After the two-year period of follow-up, we repeated for each HE the tests for the diagnosis of normal cognition and all of them fulfilled the criteria aforementioned. After the follow-up period, participants were asked to fast overnight and $20 \mathrm{ml}$ of venous blood was drawn from each subject between 7.30 and 9.00 a.m.
ApoE genotyping

Genomic DNA was extracted from whole blood by using a salting-out method [67] and ApoE genotype was determined as previously described [68].

\section{PBMC isolation}

PBMC were collected from whole blood by using a density gradient centrifugation procedure (Lympholyte-H kit Cedarlane Laboratories Limited, Burlington, $\mathrm{ON}$ ) and stored at $-80^{\circ} \mathrm{C}$ pending analysis.

\section{Flow cytometry}

TL was determined by flow cytometry using the telomere PNA kit/FITC ${ }^{\circledR}$ (Dako Italia, Milan, IT) following manufacturer's directions. This Kit allows calculating relative telomere length (RTL) of sample cells (SC) using control cells (CC) with a known TL. The tetraploid 1301 cell line (Biologic Bank and Cell Factory, Genoa, IT) with a TL of approximately $25 \mathrm{~Kb}$ [69] was used as CC. The employed PNA telomere probe binds solely the telomere repeat sequences and does not bind to subtelomeric regions, which appear to be in the range of $2-4 \mathrm{~kb}$ in length. We prepared a 1:1 mixture of $\mathrm{SC}$ and $\mathrm{CC}$, using 500,000 cells from each subject, and included 2 positive and 2 negative samples in each evaluation. In all samples, DNA was denatured for $10 \mathrm{~min}$ at $82^{\circ} \mathrm{C}$ either in the presence of hybridization solution without probe (negative) or in hybridization solution containing fluorescein-conjugated PNA telomere probe (positive). Hybridization was carried out overnight, in the dark at room temperature. After two washes at $40^{\circ} \mathrm{C}$, samples were stained with propidium iodide (PI) for $4 \mathrm{~h}$ at $4{ }^{\circ} \mathrm{C}$ for the identification of cells in G0/G1 phases and the DNA index calculation. Samples were then acquired with a FACSCanto II (Becton Dickinson, Franklin Lakes, NJ) and analyzed with a Kaluza ${ }^{\circledR}$ software (Beckman Coulter, Indianapolis, IN). For each tube, a total of 30,000 cells were analyzed. RTL was calculated with the following formula with the correction for the DNA index of G0/1 cells:

$\mathrm{RTL}=\frac{(\text { mean FL1 sample cells with probe-mean FL1 sample cells without probe }) \times \text { DNA index of control cells } \times 100}{\text { (mean FL1 control cells with probe-mean FL1 control cells without probe }) \times \text { DNA index of sample cells }}$

The absolute TL was calculated by multiplying RTL for $25 \mathrm{~Kb}$. 


\section{Telomere length polymerase chain reaction}

Genomic DNA was extracted from PBMC [68] and stored at $-80^{\circ} \mathrm{C}$ pending analysis. To confirm flow cytometry data, TL was reassessed by using a quantitative PCR (q-PCR) method as previously reported [70]. Briefly, we determined the relative ratio (T/S ratio) of telomere (T) repeat copy number to a single copy gene (S) copy number using a comparative quantitation approach. The adopted primer pairs, their final concentration and the thermal cycling profiles were exactly as described [71] except that the number of amplification cycles was increased to 30 and 40 for the $\mathrm{T}$ and $\mathrm{S}$ reactions, respectively. In each well, an aliquot of $10 \mathrm{ng}(10 \mu \mathrm{l})$ template DNA was added containing $12 \mu \mathrm{l}$ SYBR Select Master Mix (Applied Biosystem, Foster City, CA) and $3 \mu \mathrm{l}$ of primers. Before running samples, the linear range of $\mathrm{T}$ and $\mathrm{S}$ assay was determined by generating a standard curve using a serially diluted DNA (from 70 to $2.2 \mathrm{ng}$ in 2-fold dilutions) in triplicate. Both $\mathrm{T}$ and $\mathrm{S}$ reactions showed good linearity across this input range $\left(\mathrm{r}^{2}>0.99\right)$. A calibrator sample (a mixture of several DNAs) and a negative control were included on each plate. All q-PCR assays were performed on an ABI 7500 system (Applied Biosystem, Foster City, CA) and each sample, including the calibrator, was run in triplicate. For each $\mathrm{T}$ and $\mathrm{S}$ q-PCR assay, raw data were exported from the ABI system and imported into the LinRegPCR program. Then, the program automatically calculated the fluorescence threshold for all samples, the individual threshold cycle and the mean efficiency of the run [72]. Mean efficiency was used in calculating the $\mathrm{T}$ and $\mathrm{S}$ relative concentration of each sample relative to the calibrator sample [72]. TL was expressed as T/S ratio. To confirm TL measurements, all samples were re-run and the inter-assay coefficient of variation $(\mathrm{CV})$ was $<5 \%$.

\section{In vitro IL-10 production}

PBMC were resuspended at $3 \times 10^{6} \mathrm{ml}$ in complete medium (RPMI, 10\% FBS, 2\% PS, 1\% L-Glu) and were either unstimulated or stimulated with LPS (Sigma, St. Louis, MO) or with a pool of three peptides from the $A \beta$ protein as follows: fragment 1-16 $(1 \mu \mathrm{g} / \mathrm{ml})$, fragment $25-35(10 \mu \mathrm{g} / \mathrm{ml})$, and fragment $1-40(25 \mu \mathrm{g} / \mathrm{ml})$ (Innovagen, Lund, Sw) at $37^{\circ} \mathrm{C}, 5 \%$ $\mathrm{CO}_{2}$ atmosphere. Supernatants were harvested after $48 \mathrm{~h}$ for LPS stimulation and after 5 days of culture for the $A \beta$ protein peptides. Production of IL-10 by PBMC was evaluated with commercial Ready-SETGo! ELISA kit (eBioscience, Paris, Fr). The sensitivity (limit of detection) of the employed ELISA assay was $2 \mathrm{pg} / \mathrm{ml}$. All tests kits were used following manufacturer's directions and, for each sample, data on both PBMC IL-10 production and proliferation activity were also normalized based on the ratio of living/dead cells.

\section{Statistical analysis}

Statistical analysis was performed by using SPSS statistical package (SPSS version 20, Chicago, IL). Gender and $\mathrm{ApoE} \varepsilon 4$ allelic distribution across groups were assessed by the $\chi^{2}$-test. Demographic data, MMSE scores, and TL were examined by ANOVA univariate, followed by Bonferroni post-hoc test. The correlation between TLs measured by flow cytometry $(\mathrm{kb})$ and TL measured by q-PCR (T/S ratio) and between TL $(\mathrm{kb})$ and deltaMMSE scores was performed by linear regression analysis. Differences in IL-10 production between groups were evaluated by the Kruskal-Wallis test or by Mann-Whitney U-test where appropriate. Differences within groups between unstimulated and $A \beta$ stimulated IL-10 productions were assessed by the Wilcoxon signed rank test. We adopted $p<0.05$ as the threshold value for the statistical significance.

\section{RESULTS}

\section{Characteristic of study population}

Table 1 displays the demographic and clinical characteristics of participants. Despite the non-significant result obtained for the ApoE $\varepsilon 4$ distribution $(p=0.095)$, the groups show clear differences in the numbers of $\varepsilon 4$ allele carriers (Table 1 ). No difference in gender distribution (Table 1) and in the percentage of patients treated with acetylcholinesterase inhibitors was found between ADS and ADF (75\% versus 55\%, respectively, $p=0.432)$. At recruitment, $\mathrm{ADS}$ and $\mathrm{ADF}$ showed a similar mean MMSE score. Conversely, after the two-year period of follow-up, ADF exhibited a significantly lower score than ADS $(p<0.001)$. Accordingly, deltaMMSE, indicating the rate of disease progression, was significantly higher in $\mathrm{ADF}$ $(p<0.001)$ (Table 1).

\section{Telomere length analysis}

TL evaluated by the mean of flow cytometry (mean \pm S.D.) was first compared between total patients with $\mathrm{AD}$ and $\mathrm{HE}$ and no difference was found 
Table 1

Demographic and clinical characteristics of healthy elderly individuals (HE), slow-progressing AD patients (ADS) and fast-progressing AD patients (ADF)

\begin{tabular}{|c|c|c|c|c|}
\hline & $\mathrm{HE}(n=20)$ & $\operatorname{ADS}(n=20)$ & $\operatorname{ADF}(n=11)$ & $p$ value \\
\hline Age, mean \pm S.D. & $79.1 \pm 8.4$ & $80.8 \pm 5.7$ & $80.4 \pm 4.1$ & 0.919 \\
\hline Gender, female, $\%$ & 50.0 & 60.0 & 81.8 & 0.104 \\
\hline ApoE $\varepsilon 4$, carriers, $\%$ & 30.0 & 55.0 & 54.5 & 0.095 \\
\hline ApoE $\varepsilon 4$, homozygosity, $\%$ & 0.0 & 5.0 & 0.0 & 0.454 \\
\hline MMSE at recruitment, mean \pm S.D. & $29.1 \pm 1.4^{\mathrm{a}, \mathrm{b}}$ & $20.4 \pm 4.7$ & $19.9 \pm 6.1$ & $<0.001$ \\
\hline MMSE after the follow-up period, mean \pm S.D. & $28.9 \pm 1.5^{\mathrm{a}, \mathrm{b}}$ & $19.6 \pm 4.6$ & $12.3 \pm 5.4^{\mathrm{a}}$ & $<0.001$ \\
\hline deltaMMSE, mean \pm S.D. & $0.2 \pm 0.1^{\mathrm{a}, \mathrm{b}}$ & $0.8 \pm 1.4$ & $7.9 \pm 3.5^{\mathrm{a}}$ & $<0.001$ \\
\hline TL (flow cytometry), kb, mean \pm S.D. & $2.3 \pm 0.4^{\mathrm{a}}$ & $2.0 \pm 0.4$ & $2.5 \pm 0.4^{\mathrm{a}}$ & 0.003 \\
\hline
\end{tabular}

${ }^{\mathrm{a}} p<0.05$ versus ADS; ${ }^{\mathrm{b}} p<0.05$ versus ADF.
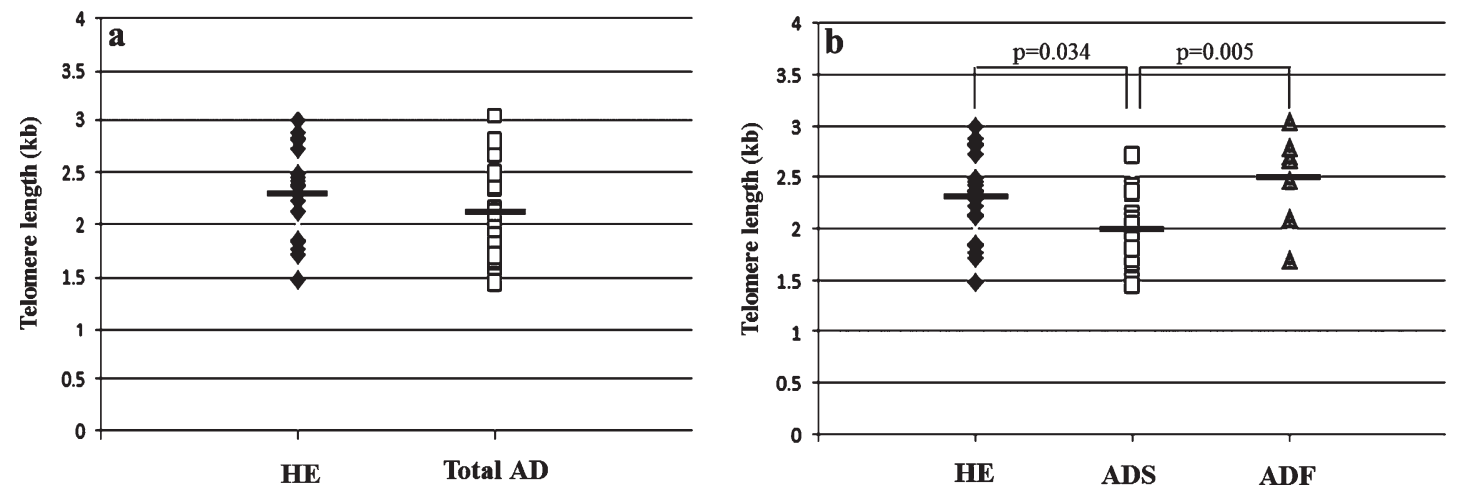

Fig. 1. Telomere length (kb) comparison between (a) HE and total AD (b) HE, ADS, and ADF.

( $2.1 \pm 0.5$ versus $2.3 \pm 0.4 \mathrm{~Kb}$, respectively, $p=0.135)$ (Fig. 1a).

Subsequently, patients were categorized as fast or slow progressing based on disease progression rate. This further classification led to the finding that ADS displayed shorter telomeres not only compared to HE ( $2.0 \pm 0.4$ versus $2.3 \pm 0.4 \mathrm{~kb} ; p=0.034)$ but also to $\operatorname{ADF}(2.0 \pm 0.4$ versus $2.5 \pm 0.4 \mathrm{~kb} ; p=0.005$ ) (Table 1 and Fig. 1b).

Patients that are homozygous for ApoE $\varepsilon 4$ have been reported to show significantly shorter TL than those with only one ApoE $\varepsilon 4$ copy or other ApoE alleles [45]. In our study population there is only one individual homozygous for ApoE $\varepsilon 4$ (Table 1), an ADS showing a TL of $2.02 \mathrm{~kb}$, which reflect the mean TL of ADS group.

In order to confirm flow cytometry data, TL measurements obtained by flow cytometry were compared to TL measurements obtained by q-PCR, showing a very strong correlation $\left(\mathrm{R}^{2}=0.523 ; p<0.001\right)$.

\section{$I L-10$ production in resting and $A \beta$ - or LPS-stimulated PBMC}

There was no difference in IL-10 production between the study groups (Table 2). In contrast, when unstimulated and $\mathrm{A} \beta$ stimulated IL-10 productions at day 5 were compared within groups, a significant

Table 2

IL-10 production from unstimulated PBMC and after stimulation with LPS or A $\beta$

\begin{tabular}{|c|c|c|c|c|}
\hline & $\mathrm{HE}(n=18)$ & $\operatorname{ADS}(n=20)$ & $\operatorname{ADF}(n=10)$ & $p$ value \\
\hline Unstimulated IL-10 production (pg/ml) (day 2), median \pm MAD & $21.0 \pm 6.0$ & $23.2 \pm 5.7$ & $16.2 \pm 4.9$ & 0.629 \\
\hline Unstimulated IL-10 production (pg/ml) (day 5), median \pm MAD & $47.1 \pm 25.4$ & $40.7 \pm 13.7$ & $39.7 \pm 14.4$ & 0.820 \\
\hline LPS-stimulated IL-10 production $(\mathrm{pg} / \mathrm{ml})$ (day 2$)$, median \pm MAD & $485 \pm 249$ & $671 \pm 285$ & $797 \pm 223$ & 0.928 \\
\hline $\mathrm{A} \beta$-stimulated IL-10 production (pg/ml) (day 5), median \pm MAD & $55.3 \pm 27.9$ & $59.0 \pm 27.0$ & $42.2 \pm 22.4$ & 0.286 \\
\hline Number of unstimulated living PBMC (millions/ml) (day 2), mean \pm S.D. & $1.54 \pm 0.28$ & $1.53 \pm 0.24$ & $1.43 \pm 0.22$ & 0.430 \\
\hline Number of unstimulated living PBMC (millions/ml) (day 5), mean \pm S.D. & $1.32 \pm 0.13$ & $1.31 \pm 0.26$ & $1.29 \pm 0.23$ & 0.932 \\
\hline Number of LPS-stimulated living PBMC (millions/ml) (day 2), mean \pm S.D. & $1.49 \pm 0.12$ & $1.41 \pm 0.12$ & $1.39 \pm 0.12$ & 0.342 \\
\hline Number of $A \beta$-stimulated living PBMC (millions/ml) (day 5), mean \pm S.D. & $1.28 \pm 0.12^{\mathrm{a}}$ & $1.30 \pm 0.26^{\mathrm{a}}$ & $1.09 \pm 0.29$ & 0.050 \\
\hline
\end{tabular}

MAD, median absolute deviation. ${ }^{a} p<0.05$ versus ADF. Missing data from 2 HE and 1 ADF. 


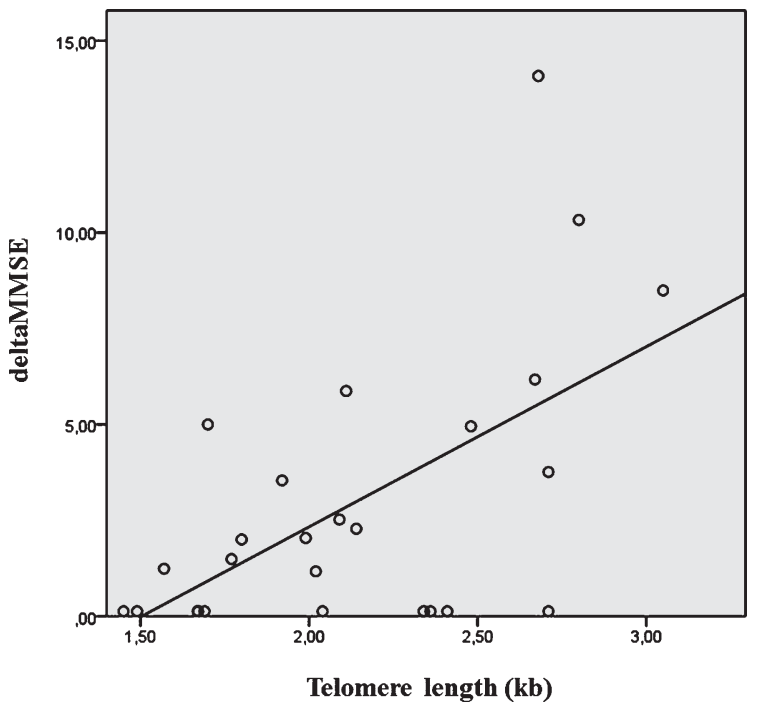

Fig. 2. Correlation adjusted for age, gender and $\mathrm{ApoE} \varepsilon 4$ genotype between TL and deltaMMSE score in patients with $\mathrm{AD}\left(\mathrm{R}^{2}=0.284\right.$; $p=0.008)$.

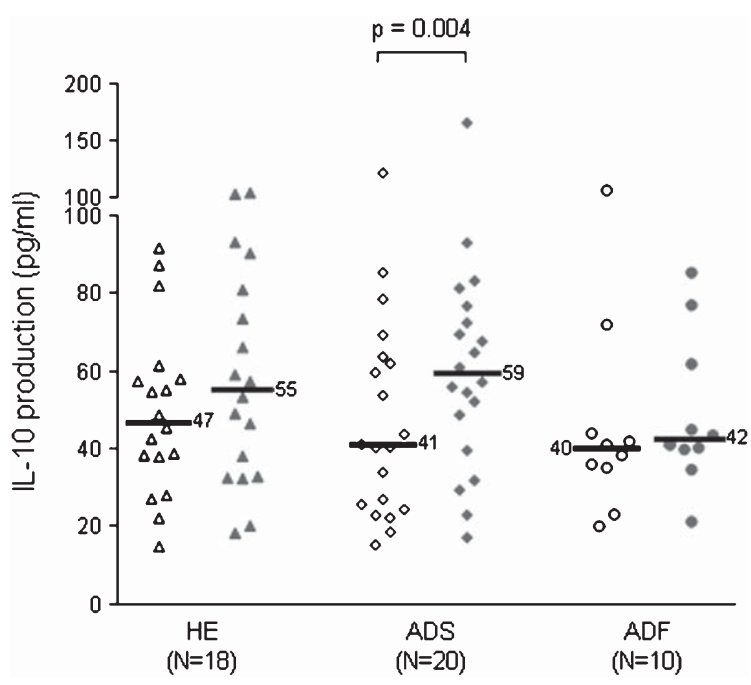

Fig. 3. IL-10 production comparison at day 5 between unstimulated (open symbols) and $\mathrm{A} \beta$ stimulated (solid symbols) PBMC.

positive difference was found in $\operatorname{ADS}(40.7 \pm 13.7$ versus 59.0 $\pm 27.0 ; p=0.004$ ) (Fig. 3). Likewise, HE showed a trend close to significance $(47.1 \pm 25.4$ versus 55.3 $\pm 27.9 ; p=0.10$ ). Interestingly, ADF did not show such a difference, suggesting a lack of response to $\mathrm{A} \beta$ stimulus $(39.7 \pm 14.4$ versus $42.2 \pm 22.4 ; p=0.94)$ (Fig. 3).

Moreover, the concentration of $A \beta$ stimulated PBMC at day 5 was significantly lower for ADF compared to both ADS $(1.09 \pm 0.29$ and $1.30 \pm 0.27$ million $\mathrm{PBMC} / \mathrm{ml}$ respectively; $p=0.050)$ and $\mathrm{HE}$ $(1.09 \pm 0.29$ and $1.28 \pm 0.12$ million $\mathrm{PBMC} / \mathrm{ml}$ respectively; $p=0.024$ ) (Table 2 ). Interestingly, we found no significant difference in the concentration of both unstimulated PBMC (after 2 and 5 days of culture) and LPS-stimulated PBMC between the study groups, suggesting that PBMC from ADF may have an impaired $A \beta$-induced but not physiologic proliferative response.

\section{$T L$ directly correlates with deltaMMSE score}

We found a direct correlation in total patients with AD between TLs (kb) and deltaMMSE scores $\left(\mathrm{R}^{2}=0.284 ; p=0.008\right)$ (Fig. 2). However, we found no significant correlation between TLs and $A \beta$-induced IL-10 production either considering all the enrolled individuals ( $p=0.448)$ or considering only the patients with $\operatorname{AD}(p=0.530)$ (data not shown).

\section{DISCUSSION}

Even though telomere shortening has been associated with neurodegeneration, dementia risk and AD etiopathogenesis, literature data have shown conflicting results. Our study showed no difference in TL between $\mathrm{AD}$ subjects compared to controls. Nevertheless, when patients were categorized based on disease progression rate, a difference in TL was found. In line with our results, a recent in vivo study showed that telomere shortening is associated with a slower cognitive decline in APP23 mice, a mouse model of AD [73].

Inflammation is considered to be involved in $\mathrm{AD}$ etiopathogenesis through effects on neuronal homeostasis and immune response [54-58]. In addition, the immune system of $\mathrm{AD}$ subjects is reported to be poorly responsive to $A \beta$ as it exhibits a reduced ability to phagocytize amyloid peptides [74] and a severe lack of proliferative responsiveness to amyloid stimulus [75]. Our previous case-control study showed a decreased $\mathrm{A} \beta$-stimulated production of IL-10 in PBMC from patients with $\mathrm{AD}$ [68], and the present data highlighted in $\mathrm{ADF}$ a lack of IL-10 increase after $\mathrm{A} \beta$ stimulus, suggesting an antigen-specific impairment in the production of this cytokine.

In addition, $\mathrm{A} \beta$-stimulated PBMC from $\mathrm{ADF}$ showed a significantly lower proliferative response when compared to $A \beta$ stimulated PBMC from both ADS and HE, also suggesting an impaired proliferative response to the stimulation induced by $\mathrm{A} \beta$ in $\mathrm{ADF}$. We speculate that PBMC from ADF may be characterized 
by an impaired capacity to respond to the inflammatory stimulus induced by $A \beta$. This may lead not only to a lower $A \beta$ induced IL-10 production but also to an impaired $A \beta$ induced proliferative response. As telomeres get shorter and shorter every time a cell divides, a reduced proliferative response to $A \beta$ may be responsible for the maintained TL in ADF. On the contrary, PBMC from ADS may be able to better respond to $A \beta$. Accordingly, an overstimulation of PBMC from ADS may occurs during the progression of the pathology, leading to both a higher proliferative and telomere shortening rate compared to ADF and HE.

Our data and APP23 mice investigations [73] showed shorter telomeres in those exhibiting a slower rate of disease progression. However, considering telomere shortening as a beneficial process with regard to the rapidity of $\mathrm{AD}$ progression requires further experimental and clinical evidences.

The strength of the present study is the further classification of AD patients in two sub-groups, which are characterized by a different progression rate (and may display different peculiar characteristics). Conversely, its weakness is the small size of the study population. This may be responsible for the lack of significant differences in IL-10 productions between groups, notwithstanding the disparity in terms of median values between ADS and ADF. The small sample size may also be responsible for the absence of significant differences in APOE $\varepsilon 4$ distribution between patients with $\mathrm{AD}$ and HE. Contributing factors to telomere shortening lie in lifestyle factors (e.g., physical activity, overall quality of life, perceived stress, smoking, nicotine and alcohol consumption) and health status. We did not compare the study groups for lifestyle factors and prevalence of age-related diseases and this may be another limitation of our study.

Our preliminary investigation confirms previous literature data suggesting PBMC as peripheral biomarkers that may mirror alterations within the diseased brain [76]. Moreover, we showed in ADF a longer TL and a lack of IL-10 increase in response to $\mathrm{A} \beta$ stimulus. The significant direct correlation between TLs and deltaMMSE scores indicates that TL may have a role as predictive marker of $\mathrm{AD}$ progression rate. The assessment of how rapidly $\mathrm{AD}$ is aggravating has important implications in clinical practice, since the rate of disease progression may be the most important factor in determining prognosis $[77,78]$.

Other investigations, with larger study groups, are necessary to clarify the mechanisms responsible for the different course of the pathology in ADS and ADF.

\section{DISCLOSURE STATEMENT}

Authors' disclosures available online (http://j-alz. com/manuscript-disclosures/14-2808r1).

\section{REFERENCES}

[1] Morris JC, Price JL (2001) Pathologic correlates of nondemented aging, mild cognitive impairment, and early-stage Alzheimer's disease. J Mol Neurosci 17, 101-118.

[2] Braak H, Braak E (1997) Frequency of stages of Alzheimerrelated lesions in different age categories. Neurobiol Aging 18, 351-357.

[3] Savva GM, Wharton SB, Ince PG, Forster G, Matthews FE, Brayne C, Medical Research Council Cognitive F, Ageing S (2009) Age, neuropathology, and dementia. N Engl J Med 360, 2302-2309.

[4] Bennett DA, Schneider JA, Arvanitakis Z, Kelly JF, Aggarwal NT, Shah RC, Wilson RS (2006) Neuropathology of older persons without cognitive impairment from two communitybased studies. Neurology 66, 1837-1844.

[5] Schneider JA, Arvanitakis Z, Bang W, Bennett DA (2007) Mixed brain pathologies account for most dementia cases in community-dwelling older persons. Neurology 69, 21972204.

[6] Kawas CH (2008) The oldest old and the 90+ Study. Alzheimers Dement 4, S56-S59.

[7] Haroutunian V, Schnaider-Beeri M, Schmeidler J, Wysocki M, Purohit DP, Perl DP, Libow LS, Lesser GT, Maroukian M, Grossman HT (2008) Role of the neuropathology of Alzheimer disease in dementia in the oldest-old. Arch Neurol 65, 1211-1217.

[8] Ferri CP, Prince M, Brayne C, Brodaty H, Fratiglioni L, Ganguli M, Hall K, Hasegawa K, Hendrie H, Huang Y, Jorm A, Mathers C, Menezes PR, Rimmer E, Scazufca M, Alzheimer's Disease I (2005) Global prevalence of dementia: A Delphi consensus study. Lancet 366, 2112-2117.

[9] Blackburn EH (2001) Switching and signaling at the telomere. Cell 106, 661-673.

[10] Blackburn EH (1991) Structure and function of telomeres. Nature 350, 569-573.

[11] Zakian VA (1995) Telomeres: Beginning to understand the end. Science 270, 1601-1607.

[12] Blasco MA (2005) Telomeres and human disease: Ageing, cancer and beyond. Nat Rev Genet 6, 611-622.

[13] Blackburn EH (2005) Telomeres and telomerase: Their mechanisms of action and the effects of altering their functions. FEBS Lett 579, 859-862.

[14] de Lange T (2002) Protection of mammalian telomeres. Oncogene 21, 532-540.

[15] Allsopp RC, Chang E, Kashefi-Aazam M, Rogaev EI, Piatyszek MA, Shay JW, Harley CB (1995) Telomere shortening is associated with cell division in vitro and in vivo. Exp Cell Res 220, 194-200.

[16] Kajstura J, Pertoldi B, Leri A, Beltrami CA, Deptala A, Darzynkiewicz Z, Anversa P (2000) Telomere shortening is an in vivo marker of myocyte replication and aging. Am J Pathol 156, 813-819.

[17] Rajaraman S, Choi J, Cheung P, Beaudry V, Moore H, Artandi SE (2007) Telomere uncapping in progenitor cells with critical telomere shortening is coupled to S-phase progression in vivo. Proc Natl Acad Sci U S A 104, 17747-17752.

[18] Vaziri H, Dragowska W, Allsopp RC, Thomas TE, Harley CB, Lansdorp PM (1994) Evidence for a mitotic clock in human 
hematopoietic stem cells: Loss of telomeric DNA with age. Proc Natl Acad Sci U S A 91, 9857-9860.

[19] Hao LY, Armanios M, Strong MA, Karim B, Feldser DM, Huso D, Greider CW (2005) Short telomeres, even in the presence of telomerase, limit tissue renewal capacity. Cell 123, 1121-1131.

[20] Blackburn EH (2000) Telomere states and cell fates. Nature 408, 53-56.

[21] Effros RB (2009) Kleemeier Award Lecture 2008-the canary in the coal mine: Telomeres and human healthspan. J Gerontol A Biol Sci Med Sci 64, 511-515.

[22] Zhang P, Dilley C, Mattson MP (2007) DNA damage responses in neural cells: Focus on the telomere. Neuroscience 145, 1439-1448.

[23] Blackburn EH, Greider CW, Szostak JW (2006) Telomeres and telomerase: The path from maize, Tetrahymena and yeast to human cancer and aging. Nat Med 12, 1133-1138.

[24] Saretzki G, Von Zglinicki T (2002) Replicative aging, telomeres, and oxidative stress. Ann N Y Acad Sci 959, 24-29.

[25] Kawanishi S, Oikawa S (2004) Mechanism of telomere shortening by oxidative stress. Ann N Y Acad Sci 1019, 278-284.

[26] Wolkowitz OM, Mellon SH, Epel ES, Lin J, Dhabhar FS, Su Y, Reus VI, Rosser R, Burke HM, Kupferman E, Compagnone M, Nelson JC, Blackburn EH (2011) Leukocyte telomere length in major depression: Correlations with chronicity, inflammation and oxidative stress-preliminary findings. $P L O S$ One 6, e17837.

[27] Aviv A (2004) Telomeres and human aging: Facts and fibs. Sci Aging Knowledge Environ 2004, pe43.

[28] Ragno M, Pianese L, Pinelli M, Silvestri S, Cacchio G, Di Marzio F, Scarcella M, Coretti F, Altamura F, Monticelli A, Castaldo I (2011) Shorter telomeres in patients with cerebral autosomal dominant arteriopathy and leukoencephalopathy (CADASIL). Neurogenetics 12, 337-343.

[29] O'Donovan A, Pantell MS, Puterman E, Dhabhar FS, Blackburn EH, Yaffe K, Cawthon RM, Opresko PL, Hsueh WC, Satterfield S, Newman AB, Ayonayon HN, Rubin SM, Harris TB, Epel ES, Health A, Body Composition S (2011) Cumulative inflammatory load is associated with short leukocyte telomere length in the Health, Aging and Body Composition Study. PLoS One 6, e19687.

[30] Der G, Batty GD, Benzeval M, Deary IJ, Green MJ, McGlynn L, McIntyre A, Robertson T, Shiels PG (2012) Is telomere length a biomarker for aging: Cross-sectional evidence from the west of Scotland? PLoS One 7, e45166.

[31] Epel ES, Merkin SS, Cawthon R, Blackburn EH, Adler NE, Pletcher MJ, Seeman TE (2009) The rate of leukocyte telomere shortening predicts mortality from cardiovascular disease in elderly men. Aging (Albany NY) 1, 81-88.

[32] Cawthon RM, Smith KR, O'Brien E, Sivatchenko A, Kerber RA (2003) Association between telomere length in blood and mortality in people aged 60 years or older. Lancet 361, 393395.

[33] Willeit P, Willeit J, Mayr A, Weger S, Oberhollenzer F, Brandstatter A, Kronenberg F, Kiechl S (2010) Telomere length and risk of incident cancer and cancer mortality. JAMA 304, 69-75.

[34] Zee RY, Castonguay AJ, Barton NS, Germer S, Martin M (2010) Mean leukocyte telomere length shortening and type 2 diabetes mellitus: A case-control study. Transl Res 155, 166-169.

[35] Fitzpatrick AL, Kronmal RA, Gardner JP, Psaty BM, Jenny NS, Tracy RP, Walston J, Kimura M, Aviv A (2007) Leukocyte telomere length and cardiovascular disease in the cardiovascular health study. Am J Epidemiol 165, 14-21.
[36] Rode L, Bojesen SE, Weischer M, Vestbo J, Nordestgaard BG (2013) Short telomere length, lung function and chronic obstructive pulmonary disease in 46,396 individuals. Thorax 68, 429-435.

[37] Buckingham EM, Klingelhutz AJ (2011) The role of telomeres in the ageing of human skin. Exp Dermatol 20, 297-302.

[38] Panossian LA, Porter VR, Valenzuela HF, Zhu X, Reback E, Masterman D, Cummings JL, Effros RB (2003) Telomere shortening in T cells correlates with Alzheimer's disease status. Neurobiol Aging 24, 77-84.

[39] Honig LS, Schupf N, Lee JH, Tang MX, Mayeux R (2006) Shorter telomeres are associated with mortality in those with APOE epsilon4 and dementia. Ann Neurol 60, 181-187.

[40] Grodstein F, van Oijen M, Irizarry MC, Rosas HD, Hyman BT, Growdon JH, De Vivo I (2008) Shorter telomeres may mark early risk of dementia: Preliminary analysis of 62 participants from the nurses' health study. PLoS One 3, e1590.

[41] Thomas P, NJOC, Fenech, M (2008) Telomere length in white blood cells, buccal cells and brain tissue and its variation with ageing and Alzheimer's disease. Mech Ageing Dev 129, 183190.

[42] Jenkins EC, Velinov MT, Ye L, Gu H, Li S, Jenkins EC Jr, Brooks SS, Pang D, Devenny DA, Zigman WB, Schupf N, Silverman WP (2006) Telomere shortening in T lymphocytes of older individuals with Down syndrome and dementia. $\mathrm{Neu}$ robiol Aging 27, 941-945.

[43] Jenkins EC, Ye L, Gu H, Ni SA, Duncan CJ, Velinov M, Pang D, Krinsky-McHale SJ, Zigman WB, Schupf N, Silverman WP (2008) Increased "absence" of telomeres may indicate Alzheimer's disease/dementia status in older individuals with Down syndrome. Neurosci Lett 440, 340-343.

[44] Hochstrasser T, Marksteiner J, Humpel C (2012) Telomere length is age-dependent and reduced in monocytes of Alzheimer patients. Exp Gerontol 47, 160-163.

[45] Takata Y, Kikukawa M, Hanyu H, Koyama S, Shimizu S, Umahara T, Sakurai H, Iwamoto T, Ohyashiki K, Ohyashiki JH (2012) Association between ApoE phenotypes and telomere erosion in Alzheimer's disease. J Gerontol A Biol Sci Med Sci 67, 330-335.

[46] Zekry D, Herrmann FR, Irminger-Finger I, Graf C, Genet C, Vitale AM, Michel JP, Gold G, Krause KH (2010) Telomere length and ApoE polymorphism in mild cognitive impairment, degenerative and vascular dementia. J Neurol Sci $\mathbf{2 9 9}$, 108-111.

[47] Zekry D, Herrmann FR, Irminger-Finger I, Ortolan L, Genet C, Vitale AM, Michel JP, Gold G, Krause KH (2010) Telomere length is not predictive of dementia or MCI conversion in the oldest old. Neurobiol Aging 31, 719-720.

[48] Valdes AM, Deary IJ, Gardner J, Kimura M, Lu X, Spector TD, Aviv A, Cherkas LF (2010) Leukocyte telomere length is associated with cognitive performance in healthy women. Neurobiol Aging 31, 986-992.

[49] Martin-Ruiz C, Dickinson HO, Keys B, Rowan E, Kenny RA, Von Zglinicki T (2006) Telomere length predicts poststroke mortality, dementia, and cognitive decline. Ann Neurol 60, 174-180.

[50] Yaffe K, Lindquist K, Kluse M, Cawthon R, Harris T, Hsueh WC, Simonsick EM, Kuller L, Li R, Ayonayon HN, Rubin SM, Cummings SR, Health ABCS (2011) Telomere length and cognitive function in community-dwelling elders: Findings from the Health ABC Study. Neurobiol Aging 32, 2055-2060.

[51] Devore EE, Prescott J, De Vivo I, Grodstein F (2011) Relative telomere length and cognitive decline in the Nurses' Health Study. Neurosci Lett 492, 15-18. 
[52] Insel KC, Merkle CJ, Hsiao CP, Vidrine AN, Montgomery DW (2012) Biomarkers for cognitive aging part I: Telomere length, blood pressure and cognition among individuals with hypertension. Biol Res Nurs 14, 124-132.

[53] Mather KA, Jorm AF, Anstey KJ, Milburn PJ, Easteal S, Christensen $\mathrm{H}$ (2010) Cognitive performance and leukocyte telomere length in two narrow age-range cohorts: A population study. BMC Geriatr 10, 62.

[54] Shastri A, Bonifati DM, Kishore U (2013) Innate immunity and neuroinflammation. Mediators Inflamm 2013, 342931.

[55] Combs CK, Karlo JC, Kao SC, Landreth GE (2001) betaAmyloid stimulation of microglia and monocytes results in TNFalpha-dependent expression of inducible nitric oxide synthase and neuronal apoptosis. J Neurosci 21, 1179-1188.

[56] Halle A, Hornung V, Petzold GC, Stewart CR, Monks BG, Reinheckel T, Fitzgerald KA, Latz E, Moore KJ, Golenbock DT (2008) The NALP3 inflammasome is involved in the innate immune response to amyloid-beta. Nat Immunol $\mathbf{9}$, 857-865.

[57] Wyss-Coray T, Yan F, Lin AH, Lambris JD, Alexander JJ, Quigg RJ, Masliah E (2002) Prominent neurodegeneration and increased plaque formation in complement-inhibited Alzheimer's mice. Proc Natl Acad Sci $U$ S A 99, 10837-10842.

[58] Reale M, Iarlori C, Feliciani C, Gambi D (2008) Peripheral chemokine receptors, their ligands, cytokines and Alzheimer's disease. J Alzheimers Dis 14, 147-159.

[59] Flanary BE, Sammons NW, Nguyen C, Walker D, Streit WJ (2007) Evidence that aging and amyloid promote microglial cell senescence. Rejuvenation Res 10, 61-74.

[60] D'Introno A, Solfrizzi V, Colacicco AM, Capurso C, Amodio M, Todarello O, Capurso A, Kehoe PG, Panza F (2006) Current knowledge of chromosome 12 susceptibility genes for late-onset Alzheimer's disease. Neurobiol Aging 27, 15371553.

[61] Guan JZ, Guan WP, Maeda T, Makino N (2012) Effect of vitamin $\mathrm{E}$ administration on the elevated oxygen stress and the telomeric and subtelomeric status in Alzheimer's disease. Gerontology 58, 62-69.

[62] Rubio-Perez JM, Morillas-Ruiz JM (2012) A review: Inflammatory process in Alzheimer's disease, role of cytokines. ScientificWorldJournal 2012, 756357.

[63] Szczepanik AM, Funes S, Petko W, Ringheim GE (2001) IL4, IL-10 and IL-13 modulate A beta(1-42)-induced cytokine and chemokine production in primary murine microglia and a human monocyte cell line. J Neuroimmunol 113, 49-62.

[64] Strle K, Zhou JH, Shen WH, Broussard SR, Johnson RW, Freund GG, Dantzer R, Kelley KW (2001) Interleukin-10 in the brain. Crit Rev Immunol 21, 427-449.

[65] McKhann G, Drachman D, Folstein M, Katzman R, Price D, Stadlan EM (1984) Clinical diagnosis of Alzheimer's disease: Report of the NINCDS-ADRDA Work Group under the auspices of Department of Health and Human Services Task Force on Alzheimer's Disease. Neurology 34, 939-944.
[66] Masse I, Bordet R, Deplanque D, Al Khedr A, Richard F, Libersa C, Pasquier F (2005) Lipid lowering agents are associated with a slower cognitive decline in Alzheimer's disease. J Neurol Neurosurg Psychiatry 76, 1624-1629.

[67] Miller SA, Dykes DD, Polesky HF (1988) A simple salting out procedure for extracting DNA from human nucleated cells. Nucleic Acids Res 16, 1215.

[68] Arosio B, Trabattoni D, Galimberti L, Bucciarelli P, Fasano F, Calabresi C, Cazzullo CL, Vergani C, Annoni G, Clerici M (2004) Interleukin-10 and interleukin-6 gene polymorphisms as risk factors for Alzheimer's disease. Neurobiol Aging 25, 1009-1015.

[69] Hultdin M, Gronlund E, Norrback K, Eriksson-Lindstrom E, Just T, Roos G (1998) Telomere analysis by fluorescence in situ hybridization and flow cytometry. Nucleic Acids Res 26, 3651-3656.

[70] Tedone E, Arosio B, Gussago C, Casati M, Ferri E, Ogliari G, Ronchetti F, Porta A, Massariello F, Nicolini P, Mari D (2014) Leukocyte telomere length and prevalence of agerelated diseases in semisupercentenarians, centenarians and centenarians' offspring. Exp Gerontol 58C 90-95.

[71] Cawthon RM (2002) Telomere measurement by quantitative PCR. Nucleic Acids Res 30, e47.

[72] Ruijter JM, Ramakers C, Hoogaars WM, Karlen Y, Bakker O, van den Hoff MJ, Moorman AF (2009) Amplification efficiency: Linking baseline and bias in the analysis of quantitative PCR data. Nucleic Acids Res 37, e45.

[73] Rolyan H, Scheffold A, Heinrich A, Begus-Nahrmann Y, Langkopf BH, Holter SM, Vogt-Weisenhorn DM, Liss B, Wurst W, Lie DC, Thal DR, Biber K, Rudolph KL (2011) Telomere shortening reduces Alzheimer's disease amyloid pathology in mice. Brain 134, 2044-2056.

[74] Fiala M, Lin J, Ringman J, Kermani-Arab V, Tsao G, Patel A, Lossinsky AS, Graves MC, Gustavson A, Sayre J, Sofroni E, Suarez T, Chiappelli F, Bernard G (2005) Ineffective phagocytosis of amyloid-beta by macrophages of Alzheimer's disease patients. J Alzheimers Dis 7, 221-232; discussion 255-262.

[75] Trieb K, Ransmayr G, Sgonc R, Lassmann H, GrubeckLoebenstein B (1996) APP peptides stimulate lymphocyte proliferation in normals, but not in patients with Alzheimer's disease. Neurobiol Aging 17, 541-547.

[76] Arosio B, D’Addario C, Gussago C, Casati M, Tedone E, Ferri E, Nicolini P, Rossi PD, Maccarrone M, Mari D (2014) Peripheral blood mononuclear cells as a laboratory to study dementia in the elderly. Biomed Res Int 2014, 169203.

[77] Carcaillon L, Peres K, Pere JJ, Helmer C, Orgogozo JM, Dartigues JF (2007) Fast cognitive decline at the time of dementia diagnosis: A major prognostic factor for survival in the community. Dement Geriatr Cogn Disord 23, 439-445.

[78] Soto ME, Andrieu S, Cantet C, Reynish E, Ousset PJ, Arbus C, Gillette-Guyonnet S, Nourhashemi F, Vellas B, group RF (2008) Predictive value of rapid decline in mini mental state examination in clinical practice for prognosis in Alzheimer's disease. Dement Geriatr Cogn Disord 26, 109-116. 